\title{
Connection of Reinforced Concrete Flat Slab and Concrete Filled Steel Tube Column: Proposed Structures, Experiment, Simulation and an Analytical Prediction Model for Shear Strength
}

\author{
Dao Ngoc the Luc, Truong Quang Hai, Truong Hoai Chinh, Dao Ngoc The Vinh
}

\begin{abstract}
Concrete filled steel tube column (CFST) combined with reinforced concrete (RC) flat slab provides potential structural solution to replace the traditional structures in high-rise buildings. The CFST column - RC slab connection is the key factor for this structure type to work effectively. This paper proposes an improved structure for connection of concrete filled steel tube column and reinforced concrete flat slabs using steel plate shear-head. The experiments of two large-sized specimens are performed to assess the capacity and reliability of the proposed connection. Numerical simulation using Abaqus is also performed to validate the test results. Based on experimental and numerical simulation results, an analytical prediction model to estimate the punching shear capacity of the flat slab is presented.
\end{abstract} Column, Flat slab, Connection.

\section{INTRODUCTION}

In the high-rise buildings, the use of beam in slab increases story height that affects the layout of the structure and efficient use of the building, especially for large span buildings. The reinforced concrete flat slab structure has many advantages such as reduction in story height, easy and fast construction, flexibility for arranging space and technical equipment systems.

Currently, the concrete fill steel tube column with great technical advantages such as high strength, high stiffness, energy dispersion and rapid construction is considered as a suitable replacement for the traditional reinforced concrete column in high-rise building construction.

Thus, the combination of CFST column and RC flat slab

Revised Manuscript Received on December 30, 2019.

* Correspondence Author

Dr. Dao Ngoc The Luc*, Director, Danang Polytechnic Institute of Science and Technology, The University of Danang - University of Science and Technology, Da Nang, Viet Nam.

Truong Quang Hai, Lecturer, Department of Civil Engineering, Mien Trung University of Civil Engineering, Viet Nam.

Dr. Truong Hoai Chinh, Associate Professor, Department of Civil Engineering, The University of Danang - University of Science and Technology, Da Nang, Viet Nam.

Dr. Dao Ngoc The Vinh, Senior Lecturer, School of Civil Engineering, The University of Queensland, Australia.

(C) The Authors. Published by Blue Eyes Intelligence Engineering and Sciences Publication (BEIESP). This is an open access article under the CC BY-NC-ND license (http://creativecommons.org/licenses/by-nc-nd/4.0/)
Keywords: Concrete filled steel tube, Reinforced concrete,

creates an effective structural system for tall buildings. CFST column - RC slab connection is the most important to ensure proper behaviour of this structure type. Some authors have investigated this connection such as Satoh H. and Shimazaki K. (2004) [1], Eder M. A. et al (2010) [2], Kim J. W. et al (2014) [3], Bompa D. V. and Elghazouli A. Y. (2016) [4].

Su Y. and Tian Y. (2010) [5] and Ju Y. K. et al (2013) [6] introduced connections with steel plates welded to the column surfaces. Su Y. and Tian Y. (2010) [5] did not to mention the anchoring method of reinforcement to column as well as the mechanism of punching shear in flat slab. Ju Y. K. et al (2013) [6] only investigated the strength of connection by ANSYS program, did not mention the punching shear capacity and the effect of the longitudinal reinforcement through column to concrete pouring.

The connections between the CFST column and RC flat slab proposed by current researches still have limitations in terms of construction and reliability. This paper proposes improved connection structures for concrete filled steel tube column with reinforced concrete flat slabs using steel plates as shear head. Experiments of two large-sized specimens are then performed to assess the behaviour and reliability of the proposed connection. Numerical simulation with Abaqus is also carried out to provide the better view on the connection behaviour. Based on experimental and numerical simulation results, the critical section perimeter is determined and used to establish an analytical model for predicting punching shear capacity of the flat slab at the connection.

\section{PROPOSED CONNECTION OF CONCRETE FILLED STEEL TUBE COLUMN TO REINFORCED CONCRETE FLAT SLAB}

As the connection between the CFST column and RC flat slab is interrupted at the steel tube surface, it is therefore important to design connection structure to ensure the integrity at the connection as well as proper behaviour of the structural system. Proposed connection structure consists of:

+ Steel plate shear head: As the quality of joint of steel plates welded to column surface is difficult to control during manufacturing and this joint is easy to break down, the steel plates are inserted inside the column through the hole on column surface and are welded to the outer surface of the column. This improvement increases the safety of the

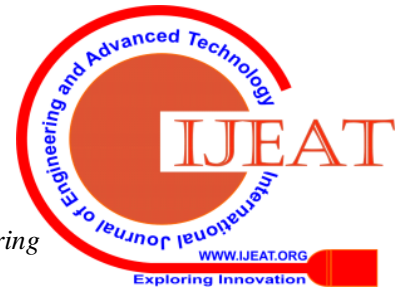


connection and punching shear for flat slab. In addition, the portion of steel plate inside column core plays a role to prevent the slip of concrete core. It should be use the least two steel plates for each column surface.

+ Stirrups around steel plate: Due to the relatively small thickness of the steel plate, concentrated stresses occur in the surrounding concrete. Thus, stirrups around steel plate are used so to distribute the load. This increases the contact area and transmits the load from the concrete to the steel plate and increases the punching shear capacity.

+ Reinforced bars anchored to column: At the connection, the top layer reinforcement must be anchored to the column. The previous anchor forms of current researches are relatively complex. This study proposes a simple anchor form for easy fabrication: the steel bars are bent at one end and inserted into the column through the holes.

+ Post-punching bar: Test results by Lee C. H. et al (2008) [7] showed that specimens with post-punching bars exhibited higher strength by $20 \%-40 \%$ and significantly increased joint stiffness by $40 \%-80 \%$ as compared to specimens without such bars. This is because the post-punching bars reinforced the concrete compression zone, thus delaying the crushing of concrete. According to ACI 352.1R-89 [8], these reinforcements may bear extra external load after the slab has been broken under the effect of dynamic loading and keeps the floor from collapsing. Therefore, in this calculation, the reinforcements should be placed in the compression zone of flat slab.
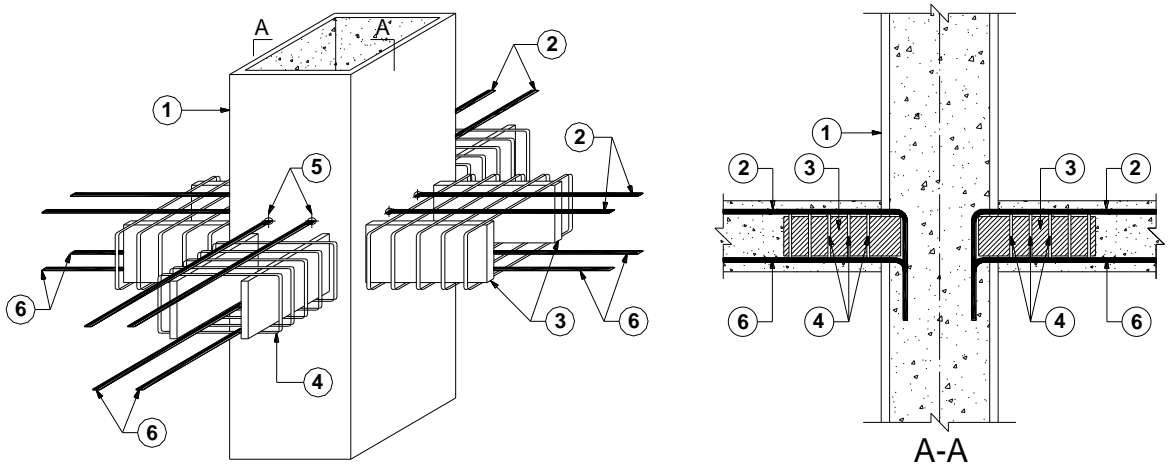

Fig. 1. Proposed CFST column - RC flat slab connection

(1) CFST column; (2) Top layer reinforcement anchored to column; (3) Steel plate; (4) Shear reinforcement; (5) Holes; (6) Bottom layer reinforcement anchored to column or Post punching bar

\section{EXPERIMENTAL PROGRAM}

To validate the strength of the proposed connection, the

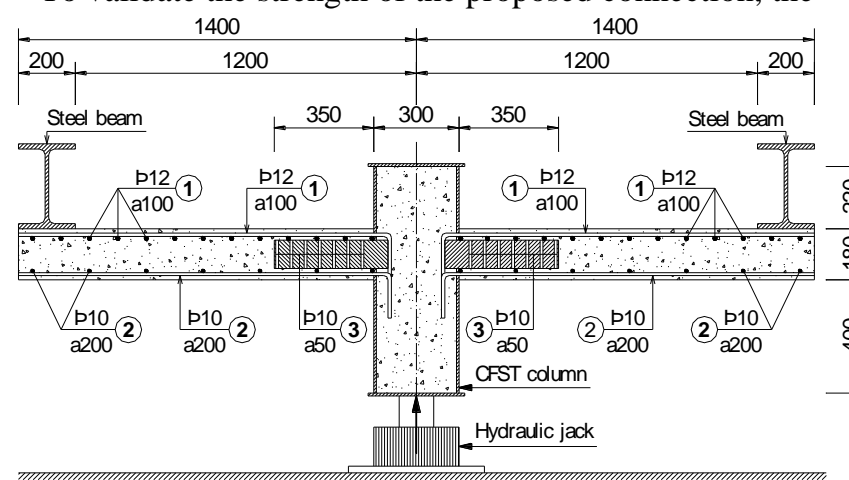

a) Specimen 1 (S1, without post-punching bars) experiment program is performed on large-sized specimens. Specimen size is based on load capacity analysis of $6 \mathrm{~m} \times 6 \mathrm{~m}$ flat slab system with slab thickness $h_{s}=180 \mathrm{~mm}$.

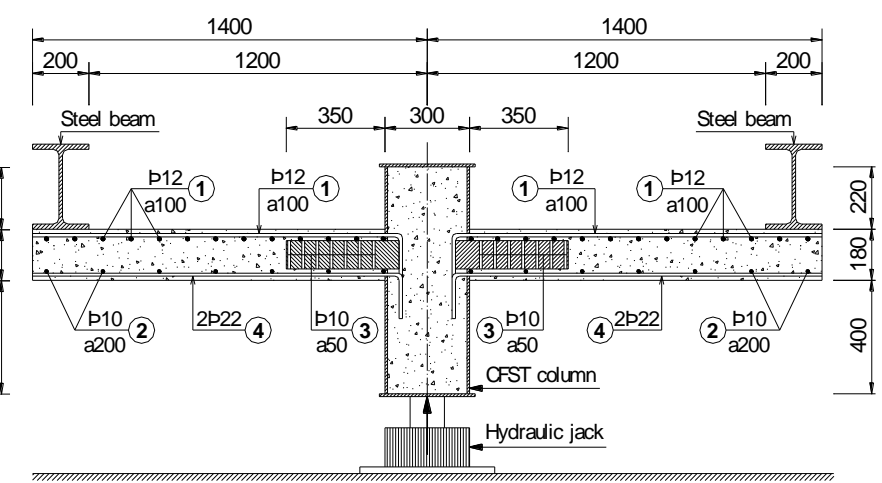

a) Specimen 2 (S2, with post-punching bars)

Fig. 2. Design details of specimen S1, S2

The design details of two specimens are the same, except: Specimen 1 (S1) does not have post-punching bars, Specimen 2(S2) has post-punching bars in the compression zone. The specimen size is given in the following Table I and material properties in Table II.

Experimental devices are used to investigate the behaviours of anchored reinforced rebars, steel plates as well as the behaviour of the slab. Strain gauge 1, Strain gauge 2 measure the deformation of the longitudinal reinforcements anchored to column . Strain gauges 3 measures steel plate deformation at the position steel plate welded to column. A load cell is located at the top of the hydraulic jack, and two linear displacement sensors (LVDTs) are located at the base of the column to measure the slab displacement as shown in Fig. 4.

\section{EPERIMENTAL RESULTS}

Loads are increased with each load level $P_{i}=20 \mathrm{kN}$ until damage occurs. Both specimens show the first crack at $\mathrm{P}=$ $140 \mathrm{kN}$. These cracks are very small perpendicular to the surface of the column and spread from the column corner to the slab edge. These cracks called radial cracks are caused by bending moments. 
Increasing load with $\mathrm{P}_{\mathrm{i}}$ level, the cracks continue to grow on the slab surface and develop evenly around the column surface with many cracks extending and spreading out to the supporting beam. The concrete floor at the adjacent side of the column has no separation from the column. In the load range from $\mathrm{P}=300 \mathrm{kN}$ to $\mathrm{P}=420 \mathrm{kN}$, the cracks develop more and the tangent cracks connect to one another with larger crack widths.

Table-I: Specimen details

\begin{tabular}{ccccccc}
\hline & $\begin{array}{c}\text { Slab thickness } \\
(\mathrm{mm})\end{array}$ & $\begin{array}{c}\text { Column dimension } \\
(\mathrm{mm})\end{array}$ & $\begin{array}{c}\text { Steel plate size } \\
(\mathrm{mm})\end{array}$ & $\begin{array}{c}\text { Top layer } \\
\text { Reinforcement }\end{array}$ & $\begin{array}{c}\text { Bottom layer } \\
\text { Reinforcement }\end{array}$ & $\begin{array}{c}\text { Stirrup } \\
\text { Post-punching bar }\end{array}$ \\
\hline S1 & 180 & $300 \times 300 \times 9$ & $400 \times 100 \times 15$ & $\phi 12 \mathrm{a} 100$ & $\phi 10 \mathrm{a} 200$ & $\phi 10 \mathrm{a} 50$ \\
S2 & 180 & $300 \times 300 \times 9$ & $400 \times 100 \times 15$ & $\phi 12 \mathrm{a} 100$ & $\phi 10 \mathrm{a} 200$ & $\phi 10 \mathrm{a} 50$ \\
\hline
\end{tabular}

Table-II: Material properties

\begin{tabular}{|c|c|c|c|c|c|c|}
\hline & $\begin{array}{c}\mathrm{f}_{\mathrm{c}}^{\prime} \\
(\mathrm{Mpa})\end{array}$ & $\begin{array}{l}\mathrm{f}_{\mathrm{y}, \text { stirrup }} \\
(\mathrm{MPa})\end{array}$ & $\begin{array}{c}\mathrm{f}_{\mathrm{y}, \text { reinforcement }} \\
(\mathrm{Mpa})\end{array}$ & $\begin{array}{c}\mathrm{f}_{\mathrm{y}, \text { steel plate }} \\
\text { (Mpa) }\end{array}$ & $\begin{array}{l}\mathrm{f}_{\mathrm{y}, \text { steel tube }} \\
\text { (Mpa) }\end{array}$ & $\begin{array}{l}\mathrm{f}_{\mathrm{y}, \text { post-punching bar }} \\
\text { (Mpa) }\end{array}$ \\
\hline S1 & 17 & 350 & 350 & 220 & 220 & 350 \\
\hline S2 & 17 & 350 & 350 & 220 & 220 & 350 \\
\hline
\end{tabular}
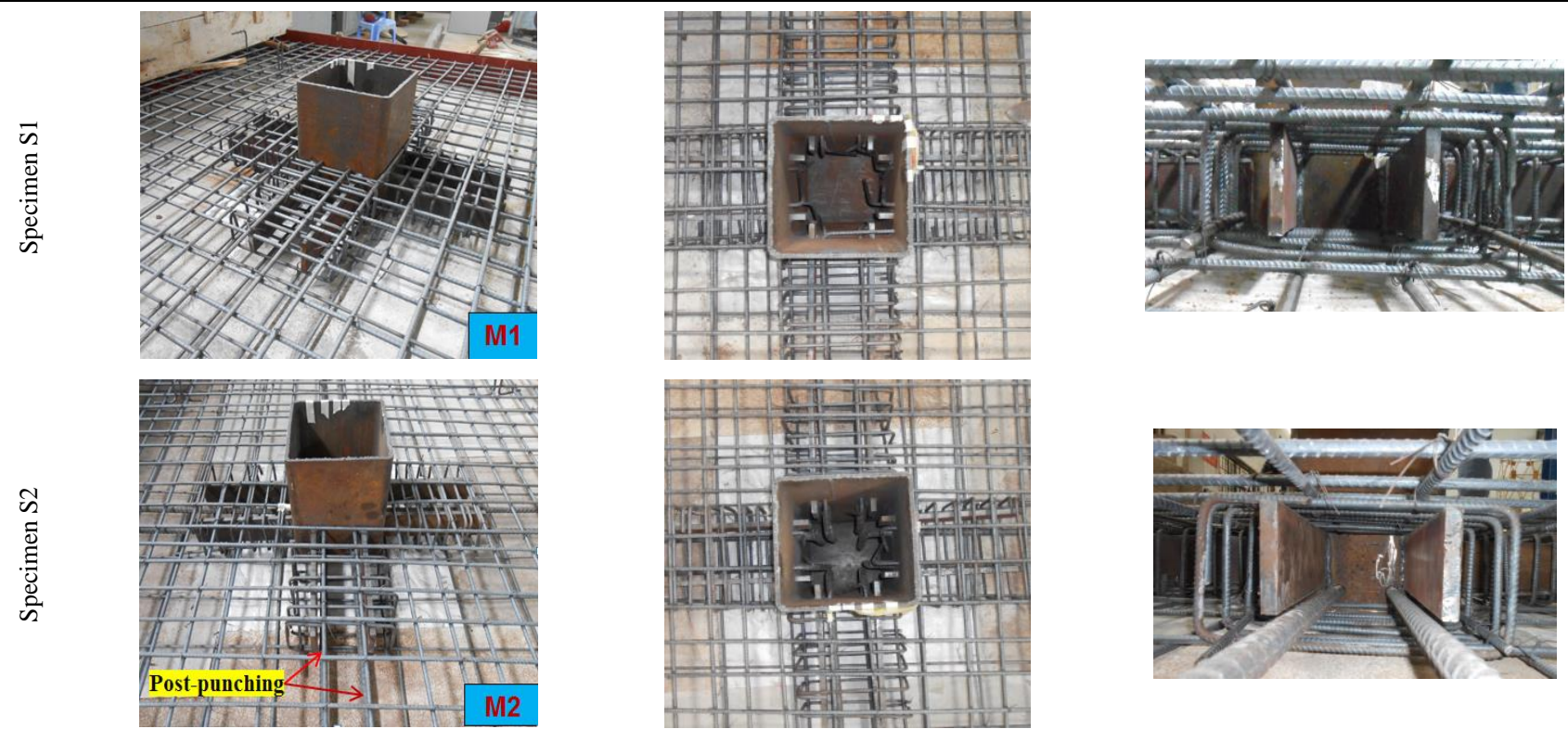

Fig. 3. Reinforcement layout of the testing specimens
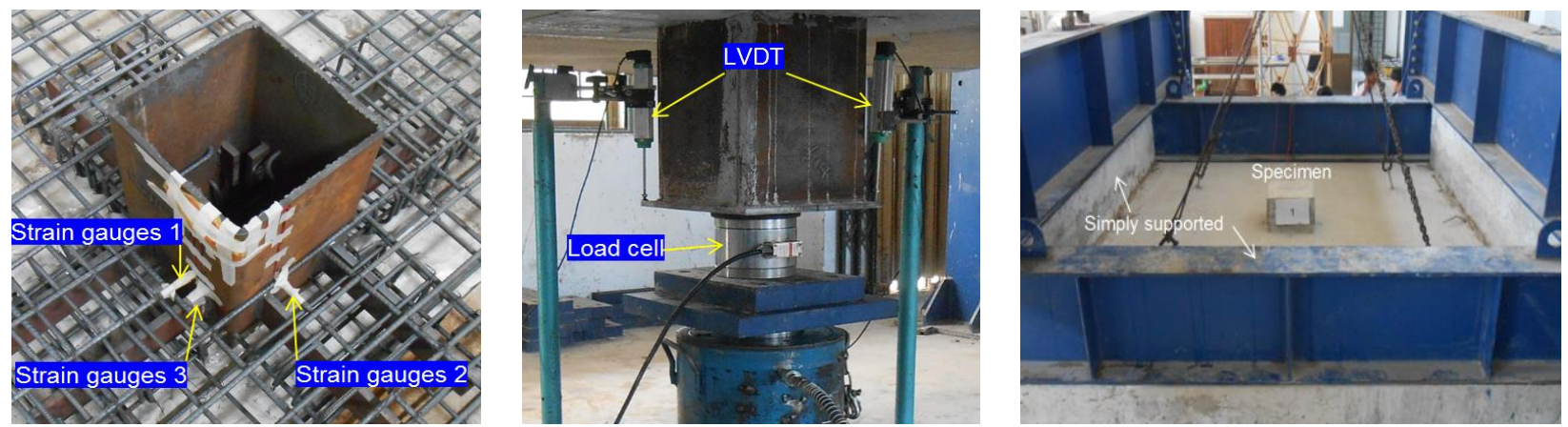

Fig. 4. The experiment set up

At $\mathrm{P}=484.6 \mathrm{kN}$ for the $\mathrm{S} 1$ and $\mathrm{P}=499.6 \mathrm{kN}$ for the $\mathrm{S} 2$, the concrete surface breaks off and the flat slab is divided into two parts, at the same time the slab is pushed up like a mushroom, the displacement of the column increases very fast, while the load decreases rapidly, proving that the connection to the flat slab is no longer loaded. The flat slab is completely damaged as shown in Fig. 5.

Thus, the behaviours of the two specimens during testing are the same. The bottom of the slab in the compression area has no failure. The post - punching reinforcements are used in the specimen S2 for the purpose of examining the possibility of increasing punching shear capacity and the results show no difference between the two cases with and without the post-punching bar.

The data obtained from the strain gauges attached to anchored reinforcements show that there is not significant difference in the reinforcement deformation in the columns of S1 and S2. The stress in the reinforcement increases with the load, indicating that the reinforced anchor solution is guaranteed.

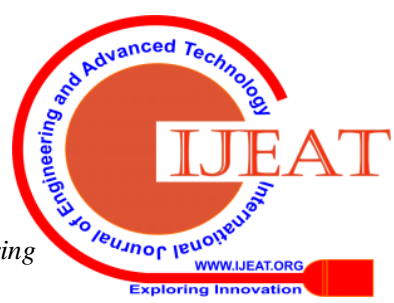




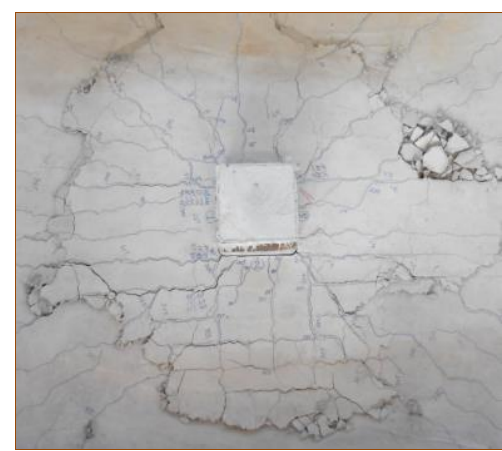

a) Specimen S1

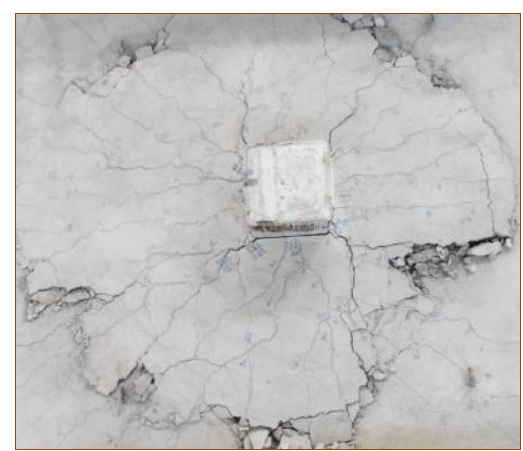

b) Specimen S2

Fig. 5. Shape of failure surface of flat slab

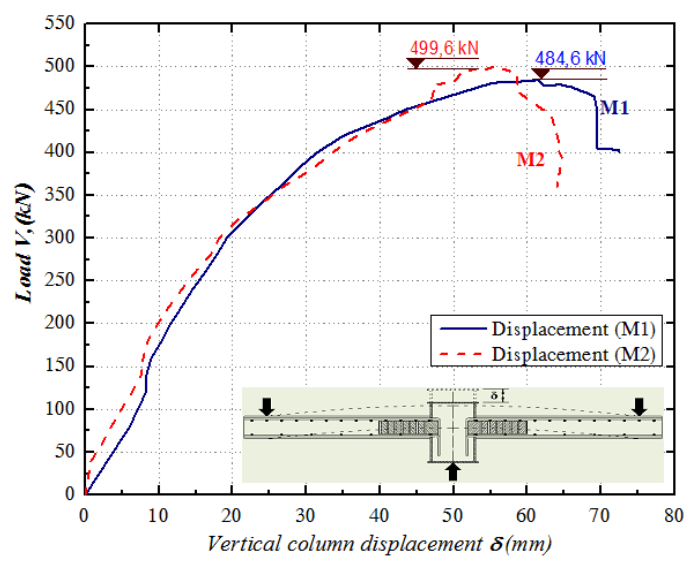

Fig. 6. Load versus vertical column displacement chart for the two specimens

\section{SIMULATION OF CFST COLUMN WITH RC FLAT SLAB CONNECTION USING ABAQUS SOFTWARE}

In this section, the Abaqus program [9] is used to simulate the connection. Abaqus software has a very rich library of elements, so choosing the right component for each element is essential. The C3D8R is selected to simulate steel tube, concrete cores, steel plates and loading plates. The T3D2 bar element is used to simulate longitudinal reinforcement and shear reinforcement. In Abaqus, each component is built into its local coordinate system (Part), independent of the model.

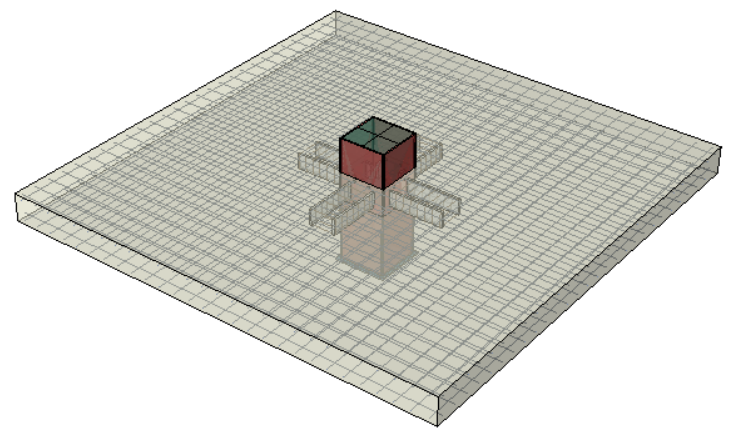

Fig. 7. Mesh for simulation of the CFST column and RC flat slab connection

Table-III: Concrete plastic damage parameters

\begin{tabular}{ccccc}
\hline $\mathbf{K}_{\mathbf{c}}$ & $\boldsymbol{\varepsilon}$ & $\boldsymbol{\sigma}_{\mathbf{b 0}} / \boldsymbol{\sigma}_{\mathbf{c 0}}$ & $\boldsymbol{\psi}$ & $\boldsymbol{\mu}$ \\
\hline 0,6667 & 0,1 & 1,16 & 13 & 0 \\
\hline
\end{tabular}

Table-IV: Interactive types used in simulation

\begin{tabular}{llll}
\hline & Elements & Interactive types & Interactive element \\
\hline RC flat slab & C3D8R & Surface to surface & CFST column \\
\hline Steel tube column & C3D8R & Surface to surface & Concrete core \\
\hline Steel plate & C3D8R & Tie & CFST column \\
\hline Longitudinal bar $\phi 10, \phi 12$ & T3D2 & Embedded element & RC flat slab \\
\hline Stirrup bar $\phi 10$ & T3D2 & Embedded element & RC flat slab
\end{tabular}


An elastic-plastic model is used to describe the steel behavior. Elastic modulus of steel is $E_{s}=2,1 \times 10^{5} \mathrm{Mpa}$, Poisson ratio by 0,3 . Longitudinal bar and reinforcement stirrup have yield stress $\mathrm{f}_{\mathrm{y}}=350 \mathrm{Mpa}$. Steel pipe and shear plate steel have yield stress $\mathrm{f}_{\mathrm{ys}}=220 \mathrm{Mpa}$.

Behaviour of concrete is described by the relationship between stress and strain on the tension and compression region. These curves are based on the theory of Alfarah B. et al (2017) [10]. In the elastic behavior, the concrete is characterized by elastic modulus and Poisson ratio, compressive strength concrete. After elastic zone, Concrete Damaged Plasticity Model (CDP) [10][11] is used to simulate the working state of the material in both the tension and the compression zone. In the Abaqus software, plastic damage state is described by parameters given in the Table III.

After meshing, load and boundary conditions are assigned to the model. In this model, the boundary conditions include joints around the perimeter of the slab. The load is applied according to the method of increasing the displacement at column.

Fig. 8 shows the load - displacement curves from experimental results and Abaqus simulation. The results show that the simulation results are quite consistent with the results of experiments.

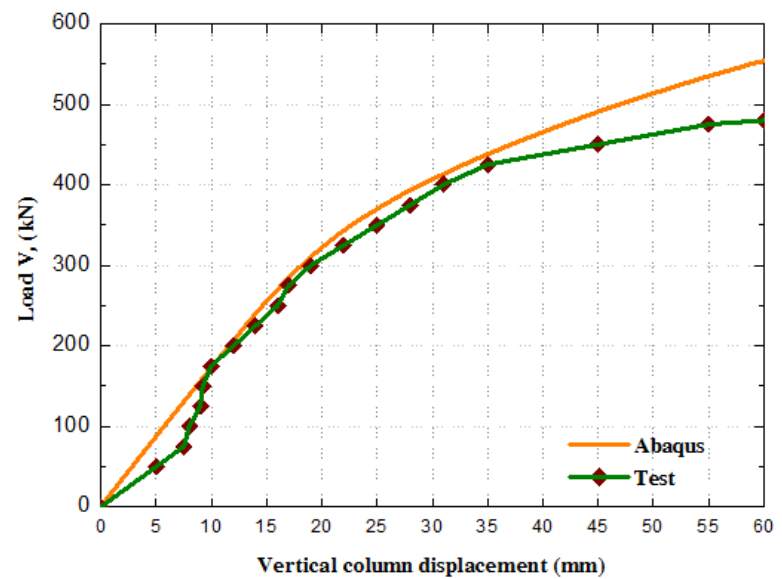

Fig. 8. The load-displacement curves of test and ABAQUS simulation
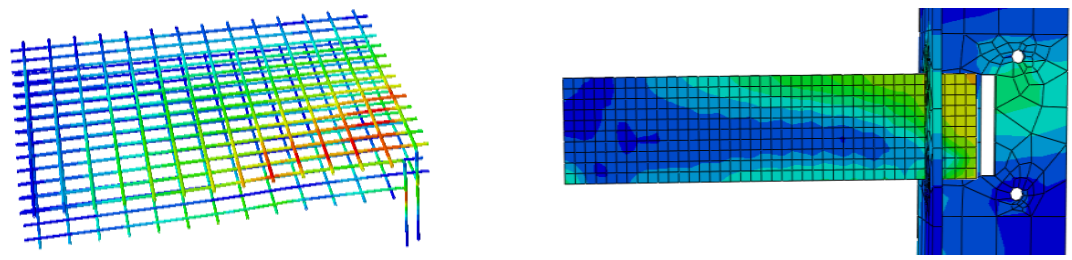

Fig. 9. Distribution of stresses in slab reinforced bars and steel plate
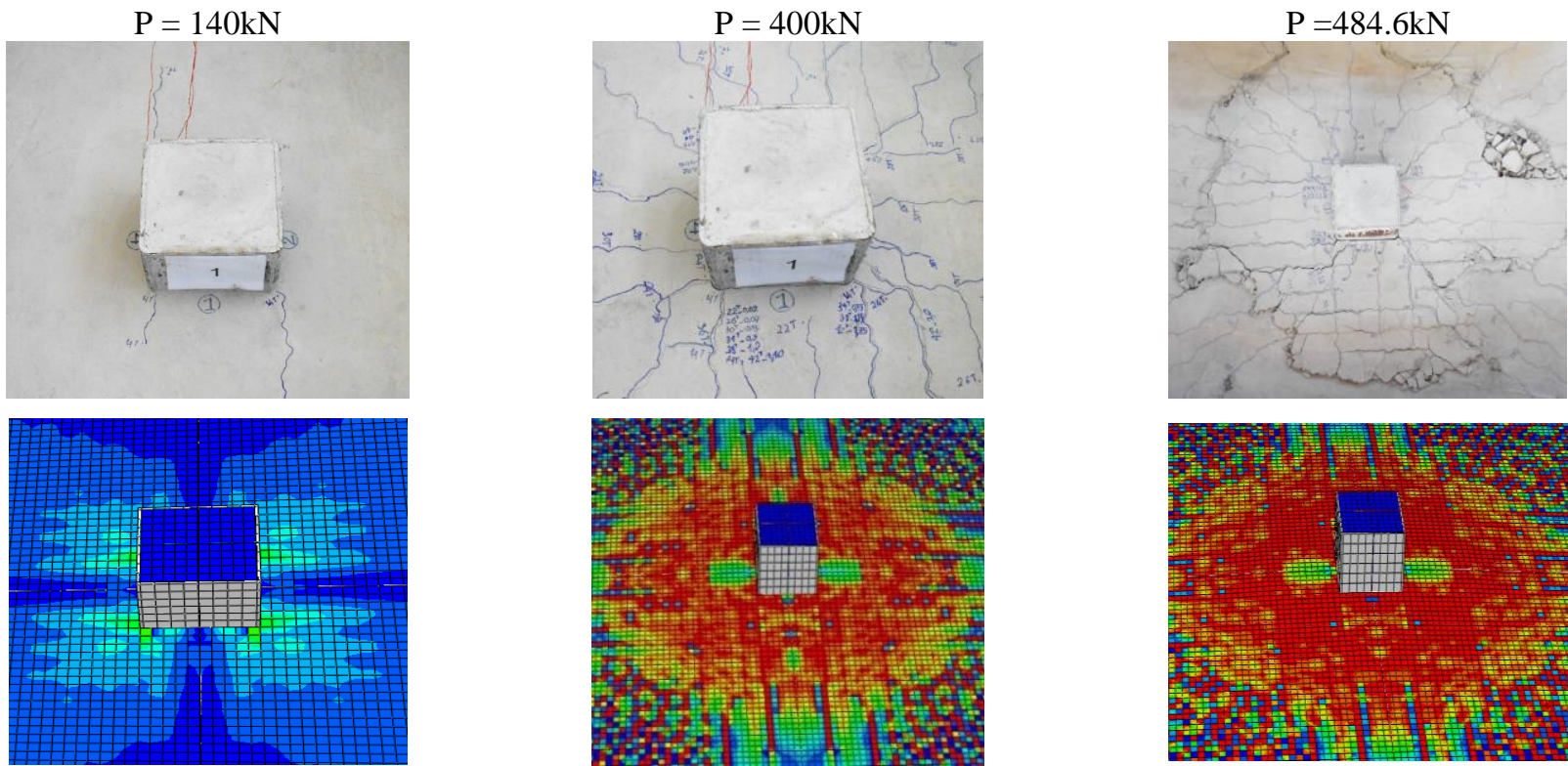

Fig. 10. Comparison of top surface behavior between simulation and experiment at different load levels 


\section{Connection of Reinforced Concrete Flat Slab and Concrete Filled Steel Tube Column: Proposed Structures, Experiment, Simulation and an Analytical Prediction Model for Shear Strength}

\section{PROPOSED ANALYTICAL PREDICTION MODEL FOR SHEAR STRENGTH}

Punching shear failures in conventional RC flat slabs are instantaneous and characterized by dislocation of a conical surface from the flat slab. Before failure, the forces are transferred from the column to the slab through a tri-dimensional strut that develops at variable inclination angles from the root of the column to the tension reinforcement, as a function of the slab thickness, flexural characteristics and material strengths [4]. However, in the case of shear-head using two steel plates as in Fig. 4, as no support for the strut to develop, the compression struts thus tend to directly transfer the compression force to the column through the folding compression struts. For the flat slab with shear-head, the presence of stirrup with distance about $\phi 10 \mathrm{a} 50$ is considered as the fulcrum for development strut. This shear crack extends from the tip of the shear head to tensile reinforcement. Whereas, the flat slab without shear-head, the crack propagation is similar to that of the reinforced concrete flat with location $d / 2$ from the column face.
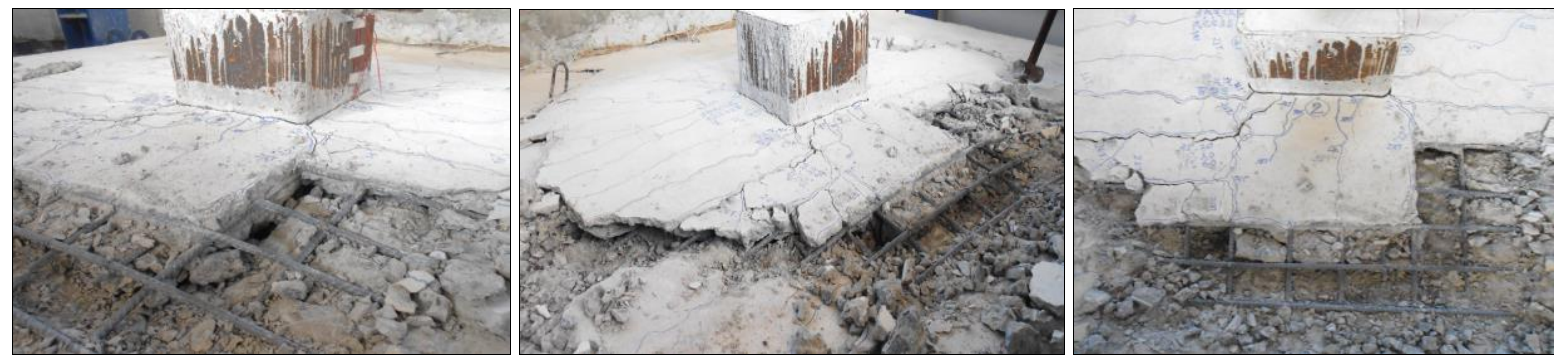

Fig. 11. Shape of failure surface of flat slab

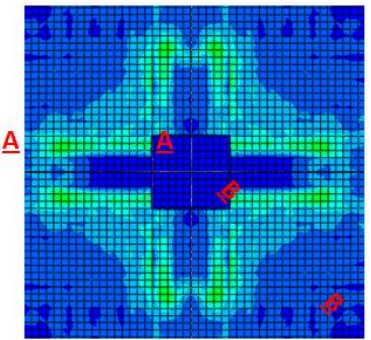

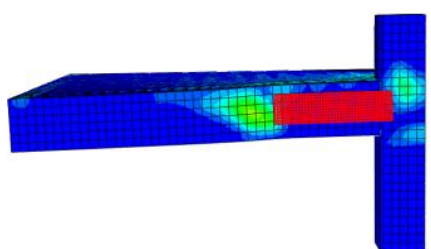

a) A-A section

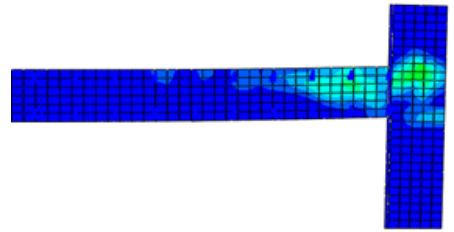

b) B-B section

Fig. 12. Cross-sections A-A and B-B from simulation results

Fig. 12 depicts cross sections at the shear head position at failure condition from simulation. The incline sections show that the high stresses occur at the tip of the shear head (A-A section) and near the corner of the column (B-B section), which conform with the experiment results in Fig. 11. The results of punching shear failure observations from experiment shown in Fig. 11 correlate well with results of the

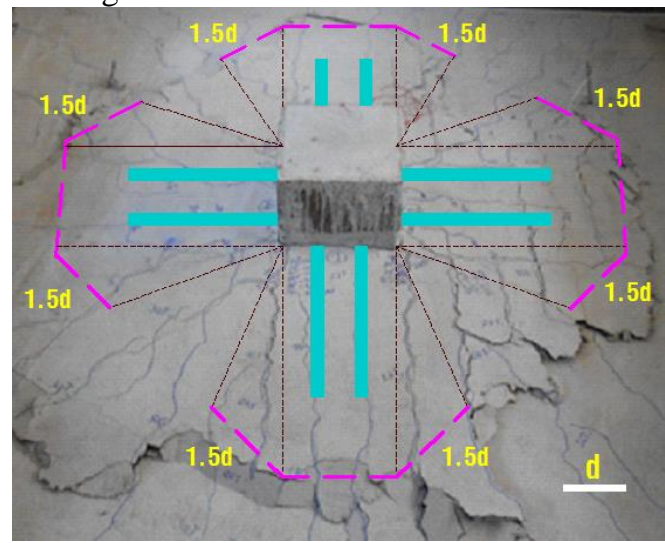

simulation by Abaqus in Fig. 12 and this is the basis for the proposed perimeter at the critical section to predict punching shear strength for the slab using the steel plate.

From Fig. 13, the perimeter of the critical section is determined according to the formula as follows:

$$
\mathrm{b}_{0}=4 \mathrm{~b}_{\mathrm{c}}+12 \mathrm{~d}
$$

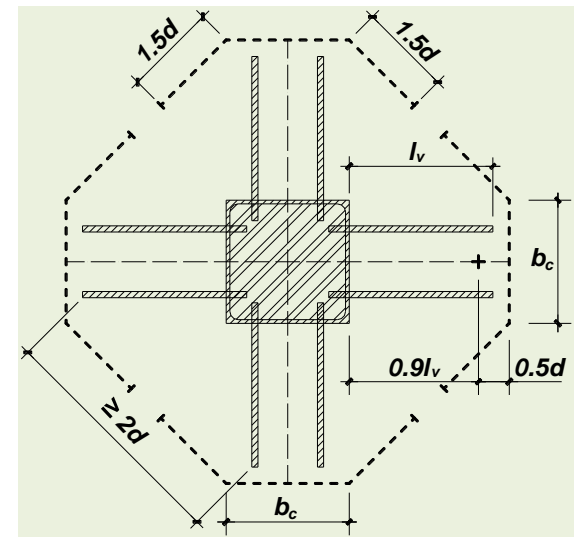

Fig. 13. Proposed critical perimeter for punching strength prediction using steel plate

The punching shear capacity of the flat slab is a function of the slab thickness, the longitudinal bar ratio and the characteristic of the material. Experimental cracks only cut through concrete. The MC 2010 [12] standard calculates the punching shear capacity based on the material characteristics of the working mechanism on the inclined cracks that is suitable for predicting the punching shear capacity of the flat slab. However, the perimeter of the critical section is not clearly defined so it is 
difficult to design. Therefore, the punching shear capacity of the flat slab at the CFST column-RC flat slab connection using steel plates without transferred reinforcement and non prestressed reinforced utilize the formula of MC 2010 with the proposed perimeter of the critical section as in equation (1):

$$
\begin{gathered}
\mathrm{V}_{\mathrm{c}}=\mathrm{k}_{\psi} \sqrt{\mathrm{f}_{\mathrm{c}}} \mathrm{b}_{0} \mathrm{~d}_{0} \\
\mathrm{k}_{\psi}=1 /\left(1.5+0.9 \cdot \psi \cdot \mathrm{d} \cdot \mathrm{k}_{\mathrm{dg}}\right) \\
\mathrm{k}_{\mathrm{dg}}=32 /\left(6+\mathrm{d}_{\mathrm{g}}\right)>0.75
\end{gathered}
$$

$$
\begin{gathered}
\psi=1.5 . \frac{\mathrm{r}_{\mathrm{s}}}{\mathrm{d}_{\mathrm{yd}}} \frac{\mathrm{f}_{\mathrm{s}}}{\mathrm{E}_{\mathrm{s}}} \\
\mathrm{b}_{0}=4\left(\mathrm{~b}_{\mathrm{v}}+3 \mathrm{~d}_{\mathrm{v}}\right)
\end{gathered}
$$

Where: $d_{g}$ - maximum aggregate size; $d_{0}$ - effective shear depth; $d$ - effective bending depth; $r_{s}$ - denotes the position where the radial bending moment is zero; $f_{y d}$ - longitudinal steel strength, $\mathrm{E}_{\mathrm{s}}$ - longitudinal elastic modulus

Table-V: Punching shear strength prediction for connection using steel plates

\begin{tabular}{ccccccccccc}
\hline $\begin{array}{c}\mathrm{b}_{\mathrm{c}} \\
(\mathrm{mm})\end{array}$ & $\begin{array}{c}\mathrm{f}_{\mathrm{yd}} \\
(\mathrm{MPa})\end{array}$ & $\begin{array}{c}\mathrm{d}_{\mathrm{g}} \\
(\mathrm{mm})\end{array}$ & $\begin{array}{c}\mathrm{f}_{\mathrm{c}} \\
(\mathrm{MPa})\end{array}$ & $\begin{array}{c}\psi \\
(\mathrm{rad})\end{array}$ & $\mathrm{K}_{\mathrm{dg}}$ & $\mathrm{k}_{\psi}$ & $\begin{array}{c}\mathrm{d}_{0} \\
(\mathrm{~mm})\end{array}$ & $\begin{array}{c}\mathrm{b}_{0} \\
(\mathrm{~mm})\end{array}$ & $\begin{array}{c}\mathrm{V}_{\mathrm{c}} \\
(\mathrm{kN})\end{array}$ & $\begin{array}{c}\mathrm{V}_{\mathrm{S} 2} \\
/ \mathrm{V}_{\mathrm{c}}\end{array}$ \\
\hline 300 & 350 & 30 & 17 & 0.0233 & 0.6957 & 0.2709 & 150 & 3000 & 502.6 & 0.96 \\
\hline
\end{tabular}

Table $\mathrm{V}$ shows the comparison between punching shears using proposed model for Specimen $1\left(\mathrm{~V}_{\mathrm{s} 1}\right)$ and Specimen 2 $\left(\mathrm{V}_{\mathrm{S} 2}\right)$ with test results. The results show the rationality of the proposed critical perimeter and possibility of using formula (1) along with the MC2010 to predict the punching shear strength the reinforced concrete flat slab connected to CFST column using shear steel plates.

\section{CONCLUSIONS}

This paper proposes an improved structure for concrete filled steel tube column with reinforced concrete flat slab connection. Connection details are relatively simple and easy to apply. Two large-sized test results confirm the strength and reliability of the connection. Experimental results with post-punching reinforced in the compression area of the flat slab do not increase the punching shear capacity but must be added to ensure the safety and integrity of the flat slab. The paper also uses Abaqus software to simulate the connection between the CFST column and the reinforced concrete flat slab. The behaviours of the specimens according to simulation and experiments are quite similar. Therefore, using the Abaqus simulation to analyze and evaluate the behavior of the connection between the CFST column and the reinforced concrete floor is sufficiently reliable. From the experimental and numerical analysis results, a critical perimeter as well as an analytical prediction model for punching shear strength of the RC flat slab accordance with MC2010 is proposed. The analytical model can be used to reliably predict the punching shear strength for reinforced concrete flat slab at connection with CFST column by shear steel plates.

\section{ACKNOWLEDGMENT}

The authors gratefully acknowledge financial support from Technology and Science Research Project funded by Vietnamese Ministry of Education and Training (Grant No. KYTH-43 (B2017.DNA.05)).

\section{REFERENCES}

1. Satoh H. and Shimazaki K. (2004), "Experimental Research On Load Resistance Performance Of CFT Column/Flat Plate Connection", $13^{\text {th }}$ World Conference on Earthquake Engineering, Canada.

2. Eder M. A., Vollum R. L., Elghazouli A. Y. and Abdel-Fattah T. (2010), "Modelling and experimental assessment of punching shear in flat slabs with shearheads", Engineering Structures, 32 (12), 3911-3924.
3. Kim J. W., Lee C. H. and Thomas H. K. K. (2014), "Shearhead Reinforcement for Concrete Slab to Concrete - Filled Tube Column Connections", Structural Journal, 111 (3)

4. Bompa D. V. and Elghazouli A. Y. (2016), "Structural performance of RC flat slabs connected to steel columns with shear heads", Engineering Structures, 117, 161-183.

5. Su Y. and Tian Y. (2010), "Experimental Study of RC Slab-CFT Column Connections Under Seismic Deformations", Opportunities and Solutions in Structural Engineering and Construction - Ghafoori, 315-320.

6. Ju Y. K., Chul Kim Y and Ryu J. (2013), "Finite element analysis of concrete filled tube column to flat plate slab joint", Journal of Constructional Steel Research, 90.

7. Lee C. H., Kim J. W. and Song J. (2008), "Punching shear strength and post-punching behavior of CFT column to RC flat plate connections", Journal of Constructional Steel Research, 64.

8. ACI 352.1R-89: Recommendations for Design of Slab-Column Connections in Monolithic Reinforced Concrete (Reapproved 1997), Technical Documents.

9. DDSS (2014) ABAQUS Analysis user's manual 6.14-2, DSS, Providence, RI, USA. 2014.

10. Alfarah B., López-Almansa F. and Oller S. (2017), "New methodology for calculating damage variables evolution in Plastic Damage Model for RC structures", Engineering Structures, 132, 70-86.

11. Lubliner J., Oliver J., Oller S. and Oñate E. (1989), “A plastic-damage model for concrete", International Journal of Solids and Structures, 25 (3), 299-326.

12. FIB (2012), Model Code 2010, Final Draft Vols $1 \& 2$.

\section{AUTHORS PROFILE}

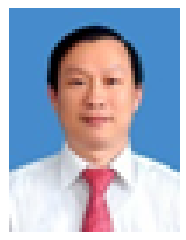

Dr. Dao Ngoc The Luc, Director, Danang Polytechnic Institute of Science and Technology, The University of Danang - University of Science and Technology, Da Nang, Viet Nam. Luc got PhD in Civil Engineering from Yonsei University (Seoul, Korea) in 2010. Luc's research interests include structural and computational mechanics, concrete engineering. Luc has published many papers in well-known national and international journals.

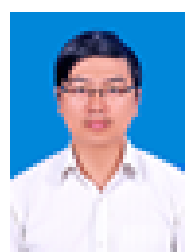

Truong Quang Hai, Lecturer, Department of Civil Engineering, Mien Trung University of Civil Engineering, Viet Nam. Hai's research interests are structural mechanics, concrete engineering. Hai has published many papers in national journals. 
Dr. Truong Hoai Chinh, Associate Professor, Department of Civil Engineering, The University of Danang - University of Science and Technology, Da Nang, Viet Nam. Chinh's research interests are concrete technology, structural engineering. Chinh has published many papers in national and international journals.

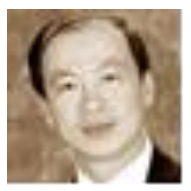

Dr. Dao Ngoc The Vinh, Senior Lecturer, School of Civil Engineering, The University of Queensland, Australia. Vinh's research interests are in the broad areas of structural engineering and fundamental behaviour of concrete/structures. Vinh is currently the Chairman of the Editorial Committee for Concrete in Australia Journal, an elected National Councillor of the Concrete Institute of Australia, a key organiser of the UQ-CCAA Advanced Concrete Technology Course and the Vice-Chair of the 16th East Asia-Pacific Conference on Structural Engineering \& Construction (EASEC-16). 